\title{
Germanium content in Polish hard coals
}

\author{
Dorota Makowska $^{1, a}$, Faustyna Wierońska ${ }^{1}$, Andrzej Strugała ${ }^{1}$ and Katarzyna Kosowska ${ }^{1}$
}

${ }^{1}$ AGH University of Science and Technology, Faculty of Energy and Fuels, al. A. Mickiewicza 30, 30-059 Krakow, Poland

\begin{abstract}
Due to the policy of the European Union, it is necessary to search for new sources of scarce raw materials. One of these materials is germanium, listed as a critical element. This semi-metal is widely used in the electronics industry, for example in the production of semiconductors, fibre optics and solar cells. Coal and fly ash from its combustion and gasification for a long time have been considered as a potential source of many critical elements, particularly germanium. The paper presents the results of germanium content determination in the Polish hard coal. 23 coal samples of various coal ranks were analysed. The samples were collected from 15 mines of the Upper Silesian Coal Basin and from one mine of the Lublin Coal Basin. The determination of germanium content was performed with the use of Atomic Absorption Spectrometry with Electrothermal Atomization (GFAAS). The investigation showed that germanium content in the analysed samples was at least twice lower than the average content of this element in the hard coals analysed so far and was in the range of $0.08 \div 1.28 \mathrm{mg} / \mathrm{kg}$. Moreover, the content of $\mathrm{Ge}$ in the ashes from the studied coals does not exceed $15 \mathrm{mg} / \mathrm{kg}$, which is lower than the average value of Ge content in the coal ashes. The highest content of this element characterizes coals of the Lublin Coal Basin and young coals type 31 from the Vistula region. The results indicate a low utility of the analysed coal ashes as a source of the recovery of germanium. On the basis of the analyses, the lack of the relationship between the content of the element and the ash content in the tested coals was noted. For coals of the Upper Silesian Coal Basin, the relationship between the content of germanium in the ashes and the depth of the seam was observed.
\end{abstract}

\section{Introduction}

In 2008 the European Commission initiated a discussion on the rare raw materials [1] resulting from China's economic policy. The first report of the working group "Raw Materials Supply Group" of the European Commission "Enterprise and Industry" was announced in 2010 [2], and the next in 2014 [3]. These reports set out the situation of raw materials in Europe and a list of elements and minerals necessary for the further development of European countries was compiled. The list includes germanium, as a critical element, which is characterized by limited resources and a lack of alternatives; at the same time it is important for the development of the world economy, especially for the electronics industry, telecommunications and automotive industries. Most of the demand for critical elements (including germanium) in the European Union is satisfied by imports from countries such as eg. China, USA, South Africa, Brazil. For this reason, it becomes necessary to search for new sources of these metals. A number of studies in the literature discussed the issue of critical raw materials for national mineral resources [4-5] and the current resource market in Poland is monitored by Mineral and Energy Economy Research Institute, Polish Academy of Sciences [6-7].

Coal and coal fly ash for a long time have been considered as a potential source of trace elements,

\footnotetext{
a Corresponding author: makowska@agh.edu.pl
}

especially germanium [8-15]. Also, Polish coals could be seen as a potential raw material for the recovery of germanium. In particular, coals from the Lublin Coal Basin were reported to contain $50 \div 1720 \mathrm{mg}$ of Ge per ton of their ash [15]. In hard coals from the Upper Silesian Coal Basin content of this element was determined in the range of $10.5 \div 52 \mathrm{mg} / \mathrm{Mg}$ [16-18]. During the 60's and 70 's of the $20^{\text {th }}$ century, J. Kuhl's research group carried out detailed investigations of the germanium occurrence in coals from the Upper Silesian Coal Basin [19-20].

Research [21] has shown that germanium is present in solid fuels regardless of its coal rank. It can be found in both the peat and lignite or in coal. In recent years, many researchers have tried to determine whether germanium is closely associated with coal mineral matter, or perhaps with any particular form of coal organic matter. Scientists have not established a clear relationship between the content of germanium in coal and the coal rank. However, it was found that there are tendencies that the content of germanium decreased with the age of coal. Studies [19] have shown that coals contain germanium partially in coal macerals and in the free, inorganic mineral matter. It was also shown that the germanium content in coals is dependent on the geological conditions of the seam and the composition of the mineral matter. Higher concentration of germanium was recorded in coals containing more calcium and magnesium carbonates, 
as well as iron compounds. In the free mineral matter Ge is associated primarily with the pyrite and the occurrence of this form can represent up to $40 \%$ of the total content of this element in coal. The highest concentration of germanium was reported in young coals type 31 in the proximity of zinc and lead deposits.

An interesting issue is how germanium has been stored in coal seams. Based on years of observation [21], no connection has been found with the storage of $\mathrm{Ge}$ during the growth of the plant, from which coal was formed. On the other hand, a number of other researchers believe that the accumulation of $\mathrm{Ge}$ by Carboniferous plants played a major role in the storage of this component in coal [19]. It is believed that the main factor influencing the amount of germanium in coal seams was Ge sorption from aqueous solutions during peat formation. It is presumed that the chemical sorption by gel humic compounds had a special significance. Therefore, the differences in the content of germanium in coals are the consequence of different conditions of the peat formation process. The thickness of the coal seam is also significant. An important role in the accumulation of germanium in coal is played by sorption from water circulating in the seam during the process of diagenesis and metamorphism, as shown by increased content of Ge in the zone near the roof and the floor of the seam.

Due to the current policy of the European Union on raw materials, the authors of this paper have researched the presence of certain critical elements (including germanium) in the waste from coal cleaning processes [22] and in fly ashes from coal combustion [23]. Aguścik [24] has made an attempt to estimate the resource of germanium in Polish coal deposits.

A number of methods for the recovery of germanium from fly ash have been used [25-27]. Currently in Spain intensive research on the recovery of germanium from the ashes produced in the coal gasification process carried out in the industrial IGCC Puertollano is being conducted [28-31].

Accordingly, coal fly ashes might be expected to be rich in germanium. The present work aimed at determining whether the Polish coals may indeed be a potential source of this precious metal. Due to the fact that germanium is recovered from coal ash obtained in industrial combustion or gasification processes, it is important to analyse the content of this element in the coals for these processes. Therefore, the content of germanium was analysed in averaged commercial coal delivered currently to Polish power plants. This was in fact the basic assumption of the preliminary analysis of the legitimacy intention of germanium recovery from the ashes, which was conducted based on the results of the research presented in the article.

\section{Experimental}

\subsection{Examined material}

The research material consisted of 23 samples of bituminous coal with different coal ranks (from steam coal to coking coal), of which 21 came from 15 mines of the Upper Silesian Coal Basin and 2 from the Lublin Coal Basin mine. The examined samples represent averaged commercial coals delivered to Polish power plants and they were taken and prepared in accordance with the standard PN-G-04502: 2014-11. All samples are listed with their specification in Table 1. For all of the samples, the determination of ash content, the content of the main ash components $\left(\mathrm{SiO}_{2}, \mathrm{Al}_{2} \mathrm{O}_{3}, \mathrm{CaO}\right.$, $\left.\mathrm{Fe}_{2} \mathrm{O}_{3}, \mathrm{MgO}\right)$ and the determination of germanium were performed.

Table 1. Examined samples specifications.

\begin{tabular}{|c|c|c|c|c|}
\hline Sample & \multicolumn{2}{|c|}{ Type of coal } & Seam & Coal \\
\hline BG-1 & steam coal & 32,2 & 300 & Lublin \\
\hline BG-2 & steam coal & 32,2 & 300 & Basin \\
\hline BO-1 & coking coal & 35,1 & 400 & \multirow{21}{*}{$\begin{array}{c}\text { Upper } \\
\text { Silesian } \\
\text { Coal } \\
\text { Basin }\end{array}$} \\
\hline $\mathrm{ZO}-1$ & coking coal & 35,1 & 400 & \\
\hline JM-1 & coking coal & 35,2 & 500 & \\
\hline KR-1 & coking coal & 34,1 & 300 & \\
\hline $\mathrm{PN}-1$ & coking coal & 35,1 & $300 / 400$ & \\
\hline BU-1 & coking coal & 34,2 & 400 & \\
\hline SB-1 & steam coal & 31,1 & $200 / 300$ & \\
\hline $\mathrm{JN}-1$ & steam coal & 31,1 & 100 & \\
\hline ST-1 & steam coal & 32,2 & $400 / 500$ & \\
\hline WR-1 & steam coal & 32,1 & 500 & \\
\hline WJ-1 & steam coal & 32,2 & $400 / 500$ & \\
\hline BB-1 & steam coal & 32,1 & 500 & \\
\hline ZM-1 & steam coal & 31,2 & 200 & \\
\hline $\mathrm{ZM}-2$ & steam coal & 31,2 & 200 & \\
\hline ZM-3 & steam coal & 31,2 & 200 & \\
\hline ZM-4 & steam coal & 31,2 & 200 & \\
\hline BŚ-1 & steam coal & 32,1 & 400 & \\
\hline BŚ-2 & steam coal & 32,1 & 400 & \\
\hline HL-1 & steam coal & 32,2 & $400 / 500$ & \\
\hline HL-2 & steam coal & 32,2 & $400 / 500$ & \\
\hline HL-3 & steam coal & 32,2 & $400 / 500$ & \\
\hline
\end{tabular}

\subsection{Analytical methods}

Coal samples were prepared in accordance with Polish standard PN-G-04502:1990. For all the samples, the determination of ash content in analytical condition was carried out in accordance with the standard PN-80 / G-04512 by slow ashing. The analysis of the main components of ash was conducted with the use of Flame Atomic Absorption Spectrometry and the determination of germanium content was conducted with the use of Graphite Furnace Atomic Absorption Spectrometry with the application of a tandem spectrometer Hitachi Z2000 with Zeeman background correction effect. As a source of radiation, hollow cathode lamps were used.

In order to perform the analyses by AAS, ash samples were subjected to complete digestion in a Berghoff SpeedWave 4 microwave system. About $100 \mathrm{mg}$ of ash was digested with spectrally pure nitric acid (V) and hydrofluoric acid. As the complexing reagent supersaturated boric acid was used. 
The determination of germanium content by GFAAS was conducted with the following parameters: analytical spectral line $265.2 \mu \mathrm{m}$; gas Ar flow $200 \mathrm{~cm}^{3} / \mathrm{min}$ (atomization $-30 \mathrm{~cm}^{3} / \mathrm{min}$ ); slit width $0.4 \mathrm{~nm}$; modifier $\mathrm{Pd}-\mathrm{Mg}$ and $\mathrm{Na}$ solution. The quantification limit of this method is equal to $0.36 \mathrm{mg} / \mathrm{kg}$ and the uncertainty of the measurement results reaches the level of $7.0 \%$ resp.

\section{Results and discussion}

Results of the determination of the ash content and the content of germanium are summarized in Table 2. The ash content of the examined samples fluctuates between 2.7 and $56.8 \%$ wt. The germanium content in the analysed samples of coal ash is lower than the world average content of germanium for coal fly ashes, which is $18 \pm 1 \mathrm{mg} / \mathrm{kg}$ [32], while calculating the germanium content in coal samples, the maximum value obtained is $1.28 \mathrm{mg} / \mathrm{kg}$, which is almost twice lower than the world average germanium content in hard coals (amounting to $2.4 \pm 0.2 \mathrm{mg} / \mathrm{kg}$ ) and even lower than the average content of this element in sedimentary rocks $(1.4 \mathrm{mg} / \mathrm{kg})$ or lithosphere $(1.7 \mathrm{mg} / \mathrm{kg})$. The results are also lower than those given in the cited literature, which may be associated with the specificity of the analysed coal samples, namely samples of averaged commercial coals currently used in combustion processes in power plants.

Table 2. Germanium content in examined samples of Polish coals.

\begin{tabular}{|c|c|c|c|}
\hline \multirow{2}{*}{ Sample } & \multirow{2}{*}{$\begin{array}{c}\text { Ash content } \\
\mathbf{A}^{\mathbf{a}}[\mathbf{\% w t}]\end{array}$} & \multicolumn{2}{|c|}{ Ge content [mg/kg] } \\
\cline { 3 - 4 } & in ash & in coal \\
\hline BG-1 & 4,3 & 10,63 & 0,46 \\
\hline BG-2 & 8,7 & 14,71 & 1,28 \\
\hline BO-1 & 56,8 & 1,02 & 0,58 \\
\hline ZO-1 & 52,7 & 1,04 & 0,55 \\
\hline JM-1 & 22,2 & 0,95 & 0,21 \\
\hline KR-1 & 46,0 & 2,26 & 1,04 \\
\hline PN-1 & 53,4 & 1,62 & 0,87 \\
\hline BU-1 & 36,9 & 2,40 & 0,89 \\
\hline SB-1 & 6,5 & 4,10 & 0,27 \\
\hline JN-1 & 8,7 & 10,98 & 0,96 \\
\hline ST-1 & 20,3 & 4,50 & 0,91 \\
\hline WR-1 & 2,7 & 3,23 & 0,09 \\
\hline WJ-1 & 16,7 & 0,72 & 0,12 \\
\hline BB-1 & 9,5 & 2,84 & 0,27 \\
\hline ZM-1 & 7,1 & 7,88 & 0,56 \\
\hline ZM-2 & 6,4 & 3,11 & 0,20 \\
\hline ZM-3 & 6,7 & 4,15 & 0,28 \\
\hline ZM-4 & 21,4 & 5,13 & 1,10 \\
\hline BŚ-1 & 17,5 & 1,83 & 0,32 \\
\hline BŚ-2 & 29,9 & 3,56 & 1,06 \\
\hline HL-1 & 13,8 & 0,56 & 0,08 \\
\hline HL-2 & 29,2 & 1,59 & 0,46 \\
\hline HL-3 & 7,7 & $<$ LOQ & - \\
\hline & & & \\
\hline & & & \\
\hline
\end{tabular}

In order to verify the association of germanium with mineral matter, the relationship between the content of this element (in both coal samples and its ashes) and ash content was examined (Fig. 1). It can be concluded that there is no correlation between the content of germanium in the examined coals and ash content. Similarly, the correlation between the content of Ge in ash and ash content is relatively low. It can be observed, however, that coals with low ash content have the highest concentration of Ge.

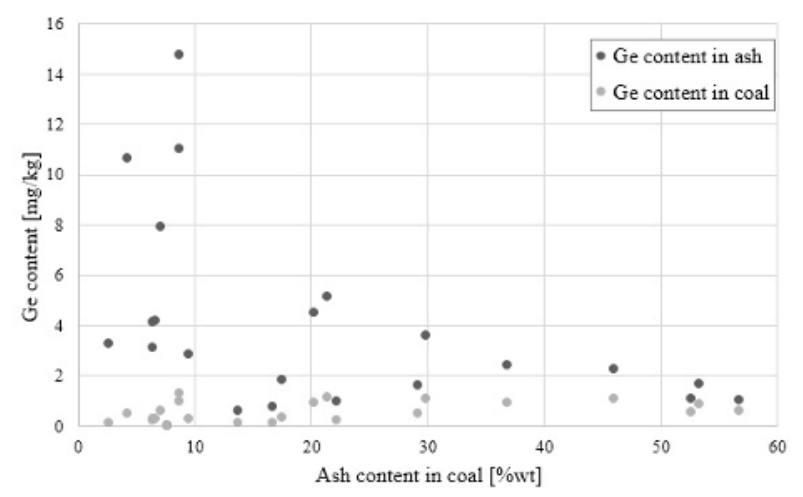

Figure 1. Relationship between germanium content in examined coals and their ashes, and ash content in coal.

The dependence of the seams depth on germanium content was also examined (Fig. 2). The presented graph indicates the presence of the correlation between the content of the tested element and the depth of the seam for coals from the Upper Silesian Coal Basin; the deeper the seam is located, the smaller the content of germanium becomes. However, due to the amount and type of the analysed samples shown in Fig. 2 generalized conclusions cannot be drawn on the correlation between the group of coal seam and the content of germanium. It would be possible based on the examination of a large amount of geological samples. The presented graph is merely aimed at showing the results only within the framework of this work.

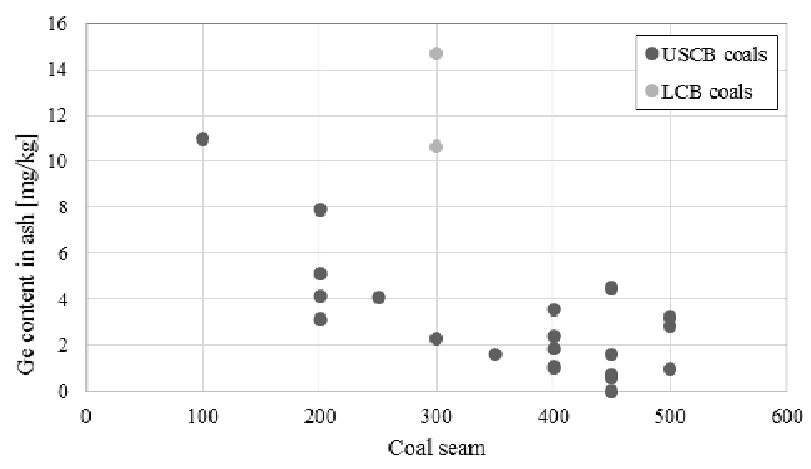

Figure 2. Germanium content in examined coal ashes in relation to seam group of analysed coals.

A similar correlation can be observed in the case of the relationship between the germanium content in ash and the type of coal (Fig. 3), namely, the higher coal rank of the examined samples is, the lower the germanium content becomes. 
Therefore, these results confirm the tendency of the content of this element to decrease along with the age of coal.

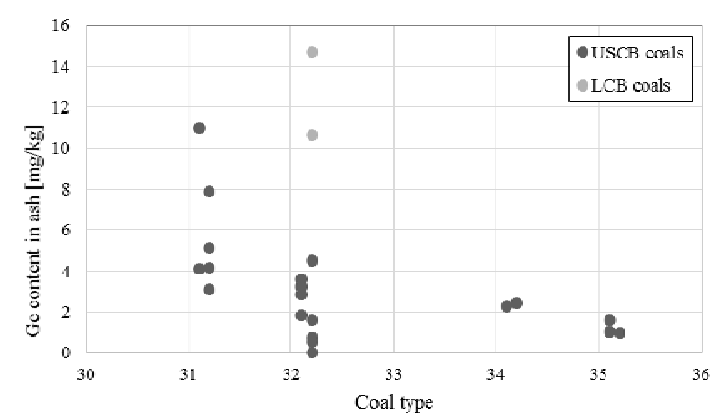

Figure 3. Relationship between germanium content in examined coal ashes and coal type.
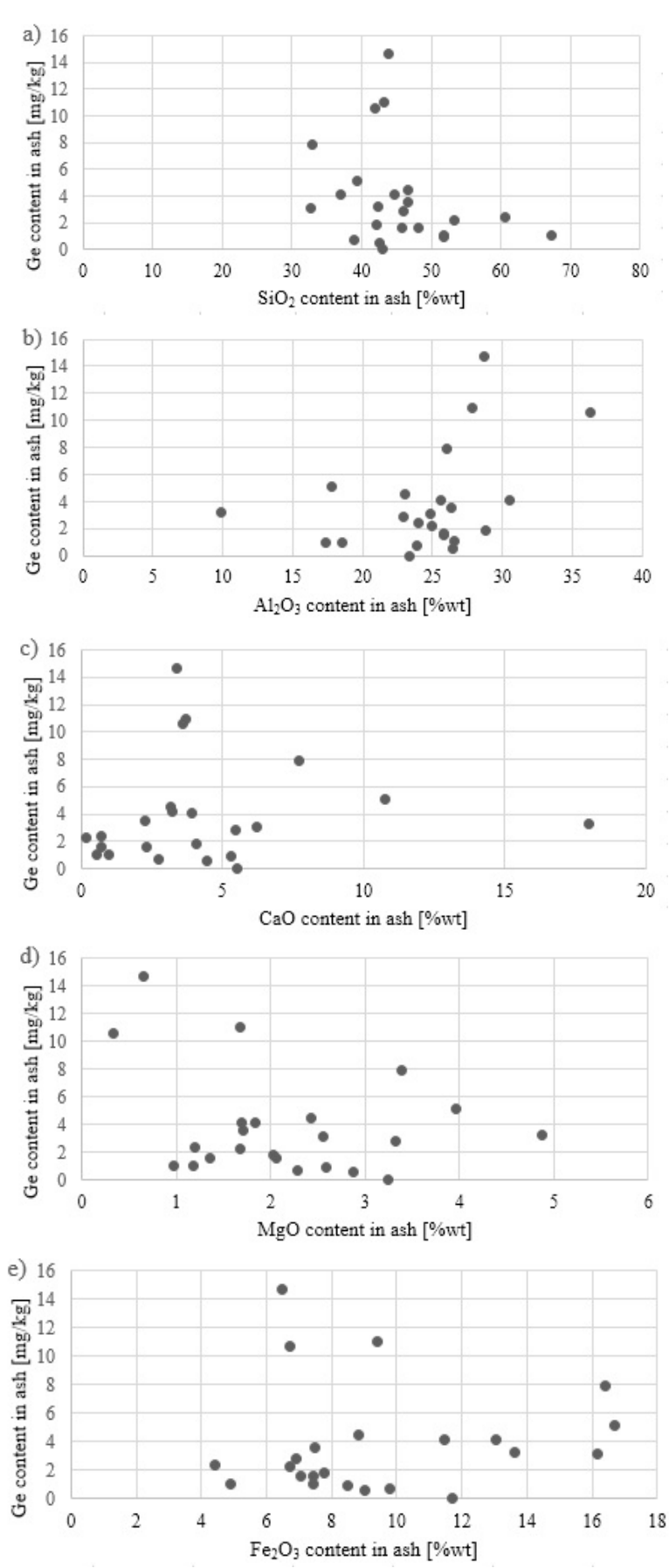

Figure 4. Relationship between germanium content in examined coal ashes and content of main ash compounds: a) silicon; b) aluminium; c) calcium; d) magnesium and e) iron.

Based on the analysis of ash composition of the examined samples, the impact of the individual components of the mineral matter on the accumulation of germanium in coal was also examined. The correlation between the Ge content and the content of $\mathrm{SiO}_{2}, \mathrm{Al}_{2} \mathrm{O}_{3}$, $\mathrm{CaO}, \mathrm{Fe}_{2} \mathrm{O}_{3}, \mathrm{MgO}$ is shown in Fig. 4 .

The presented graphs show no relationship between the germanium content in the examined coal ashes and the content of each of the main ash components. As a result, the findings of the earlier research [19] have not been confirmed.

To determine whether the ashes from the examined Polish coals can be considered as a potential source 
of germanium, the Enrichment Factor $E F$ was calculated for each ash sample from the equation below (1) and plotted in Fig. 5.

$$
E F=\frac{A_{e}}{A_{c}}
$$

Where $A_{e}$ is the concentration of Ge in the fly ash sample $(\mathrm{mg} / \mathrm{kg})$ and $A_{c}-$ the average Ge content in sedimentary rocks $(\mathrm{mg} / \mathrm{kg})$. The graph also presents the Coal Affinity Index $C A I$ [32]. This index defines the ratio of the world average content of germanium in coal ashes to its average concentration in sedimentary rocks.

The Enrichment Factor for most of the analysed samples is greater than 1.0 , but no value exceeded $C A I$. The highest values of $E F$ were observed for coal samples from the Lublin Coal Basin and the coal samples from the Vistula region ( $\mathrm{JN}-1$ and $\mathrm{ZM}-1$ ).

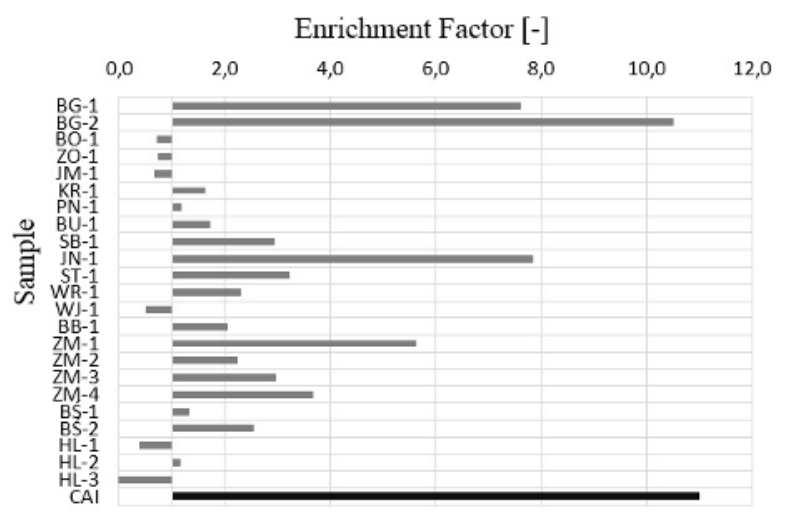

Figure 5. Germanium enrichment factor for examined coal samples.

\section{Conclusions}

The aim of the study was to update the information on the content of germanium in Polish coals and to evaluate ashes from these coals as a potential source of germanium. Based on extensive investigations, the following conclusions can be drawn:

- germanium content in the examined Polish coals does not exceed the average content of this element in the earth's crust;

- no relationship between the Ge content in the samples and ash content was noticed, although the highest content of this element in the ash was determined in coals with the lowest ash content;

- no association was found between the content of germanium in the ash and the content of each of the main elements of mineral matter, i.e. $\mathrm{Si}, \mathrm{Al}, \mathrm{Ca}, \mathrm{Mg}$, Fe;

- germanium content in the ashes of the analyzed samples is lower than the world average germanium content in the coal ashes, which indicates the usefulness of the examined coal ashes as a raw material for the recovery of germanium, however, these results cannot exclude the possibility of recovery of this element in the future, when other coal seams are operated.
- the biggest Enrichment Factors have been noted for the samples of coal from the Lublin Coal Basin and the coals from Vistula region.

\section{Acknowledgements}

This paper was prepared as a part of the statutory activity of the Faculty of Energy and Fuels at the AGH University of Science and Technology, No. 11.11.210.213

\section{References}

1. The Raw Materials Initiative - Meeting our critical needs for growth and jobs in Europe, Commission of the European Communities, Brussels 2008

2. Critical Raw Materials for The EU. Report of the Adhoc Working Group on defining critical raw materials, Raw Materials Supply Group, Brussels 2010

3. Report on Critical Raw Materials for The EU. Report of the Ad-hoc Working Group on defining critical raw materials, Brussels 2014.

4. B. Radwanek-Bąk, Mineral Resources Management 1, 5-19, (2011)

5. T.J. Smakowski, Bulletin of the Mineral and Energy Economy Research Institute of the Polish Academy of Science 81, 59-68 (2011)

6. T.J. Smakowski, T. Galos, E. Lewicka [red.], Bilans gospodarki surowcami mineralnymi Polski $i$ świata 2013 (IGSMiE PAN, Warsaw 2015)

7. A. Burkowicz, K. Galos, K. Guzik, et al., Minerals Yearbook of Poland 2012 (IGSMiE, Warsaw 2013).

8. J. Całus-Moszko, B. Białecka, Mineral Resources Management 29 (1), 67-80 (2013)

9. G. Eskenazy, Fuel and Energy Abstracts 37, 3, 170 (1995)

10. M. Marczak, Geneza i prawidłowość występowania pierwiastków śladowych $w$ węglach złoża Chetm $w$ Lubelskim Zagtębiu Weglowym (Wydawnictwo Uniwersytetu Śląskiego, Katowice 1985)

11. M. Mastalerz, A. Drobniak, Int. J. Coal Geol. 94, 302313 (2012)

12. H.R. Parzentny, Wpływ nieorganicznej substancji mineralnej na zawartość niektórych pierwiastków śladowych $w$ weglu Górnośląskiego Zagłębia Weglowego (Wydawnictwo Uniwersytetu Śląskiego, Katowice 1995)

13. V.V. Seredin, R.B. Finkelman, Int. J. Coal Geol. 76, 253-289 (2008)

14. Ya.E. Yudovich, Int. J. Coal Geol. 53, 223-232 (2003)

15. M. Plewa, Pierwiastki śladowe w węglu Lubelskiego Zagtębia Węglowego, II Seminarium: Metodyka rozpoznawania $i$ dokumentowania złóż kopalin statych (Wydawnictwo AGH, Kraków 1990).

16. S. Cebulak, A. Różkowska, Geological Quarterly 27 (1983)

17. A. Różkowska, Geological Exploration Technology no 2 (1984)

18. A. Idzikowski, Arch. Miner. 23, no 2, 271 (1959)

19. J. Winnicki, Prace GIG 18, Komunikat 354, 159-195 (1964)

20. J. Winnicki, Praca Naukowa Instytutu Chemii Nieorganicznej i Metalurgii Pierwiastków Rzadkich Politechniki Wrocławskiej no 18 (1975)

21. K. Akerman, German (WNT, Warsaw 1967) 
22. A. Strugała, D. Makowska, K. Bytnar, et al., Energy Policy Journal 17 (4), 77-88 (2014)

23. D. Makowska, F. Wierońska, GeoScience Engineering 62, no 1, 31-36 (2016)

24. J. Aguścik, Bulletin of the Mineral and Energy Research Institute of the Polish Academy of Sciences 88, 8-13 (2014)

25. R.S. Blissett, N.A. Rowson, Fuel 97, 1-23 (2012)

26. V.G. Nosach, et al., Fuel and Energy Abstracts 38 (6), 431 (1997)

27. L. Zhang, Z. Xu. Z., Journal of Hazardous Materials, 312, 28-36 (2016)

28. F. Arroyo, F.A. Torralvo, C. Fernandez-Pereira, Minerals Engineering 24, 35-41 (2011)

29. F. Arroyo, et al., Fuel Processing Technology 124, 222-227 (2014)

30. O. Font, X. Querol, A. Lopez-Soler, et al., Fuel 84, 1384-1392 (2005)

31. A.S. Meawad, D. Bojinova, Y.G. Pelovski, Waste Management 30, 2548-2559 (2010)

32. M.P. Ketris, Ya.E. Yudovich, Int. J. Coal Geol. 78, 135-148 (2009) 